\title{
Getting Inside Sophocles' Mind Through Hölderlin's Antigone
}

\author{
Kathrin H. Rosenfield
}

Readers of Hölderlin are familiar with the truly tragic circumstances surrounding his translations and commentaries on Sophocles' tragedies. 1 The young poet, impressed with the beauty of Johann Heinrich Voss's translations of Homer and influenced by Goethe's cautions against excessive philosophical abstraction, endowed his translations with both poetic sensibility and theoretical insight $\stackrel{2}{2}$ in equal proportion. The negative reception they received, especially the rejection and ridicule at the hands of the philologist H. Voss (the great translator's son) seems to have precipitated Hölderlin's mental breakdown. Voss's review must be read carefully to understand the deep sense of isolation which Hölderlin must have felt in the face of the profound chasm that separated his own outlook and thinking from that of the philologist. Apparently impartial and objective at first, Voss's appraisal grows increasingly savage while his mocking criticism veils his own erroneous assumptions and the theoretical biases on which they rest--for example, the commonly held notion that the tragic poets were representatives of the "clear" and "rational" Greek thought, expressing itself through the "clearly defined characters" of the classical gods, which were supposed to be immediately understandable to the "common sense." $\underline{3}$

Hölderlin's treatment of the logical structures of mythic thought underlying classical poetry was remarkably insightful. However, his rather obscure formulations as to the links between Sophocles' rational discourse and the ancient, mythical contexts offended Voss's notions about the nobility and rationality of the divine and human characters in classical Greek tragedy. Extremely sensitive to the logical, intellectual and "reasoning" ("pensantes") implications of the figurative movement in poetry and myth, Hölderlin detected in the Sophoclean tragedies certain wordplays based entirely on the production of meaning through stylistic contrasts. These contrasts operate at the level of affective and emotional relationships that are charged with latent or virtual cognitive signifiers. In another article I investigated the relationship between Hölderlin's philosophical fragments and his reading of myth and [End Page 107] tragedy which is at once both emotional and rational. 4 Let us briefly go over the major points of Hölderlin's attempt to get at the implicit (non-discursive) thought of poetic form. This figurative mode of expression avoids the limitations of abstract, conceptual thinking, which is inadequate in the domains of aesthetics and of practical, active life.

Hölderlin's starting point is Kant's philosophy or, to be more precise, a critique of the scholarly application of Kantian concepts to aesthetic and artistic reality, such as Schiller's aesthetics. Like Goethe, who saw abstract ideas as the horizon of experience, ${ }_{5}^{5}$ Hölderlin tried to move away from the abstraction of discursive and conceptual propositions by broadening the Kantian notion of "free play of the faculties of the soul." $\underline{6}$ In the Critique of Judgment Kant's distinction between moral 
ideas, scientific knowledge and aesthetic judgment derives from a single a priori faculty that is the intellectual foundation of all three types of rational activity. This new centrality of aesthetics is the starting point for Hölderlin's examination of the role of the senses and of feelings in the realm of theoretical, intellectual activity. Hölderlin introduces the idea of an "interior intensity" (das Innige, that is, the intuition of an all-embracing unity prior to the distinctions of experience and of conceptual thinking). ${ }^{7}$ According to Hölderlin, our aesthetic sense conceives of this principle in a "divinatory" manner, and (tragic) poetry furnishes the figures of this pure wisdom: it is the "metaphor of an intellectual intuition." Thus Hölderlin conveys to poetry a theoretical status: it becomes the link between concrete experience and abstract ideas, a link which is independent from practical reason.

This substructure encompasses all our sense and intellectual activity at the level of aesthetic experience and operates through gradations of rhythm, tone, and Stimmung, giving a melodious cohesiveness to propositions $\underline{8}$ that are not necessarily logical, coherent, and rational in themselves (that is to say, considered independently without regard to the whole). Translating Sophocles, Hölderlin tried to give expression to this theoretical framework which, in fact, infuses all his poetry. In his translations he opens up a surprising multiplicity of perspectives and uncovers unforeseen points of view through a wealth of nuance and emotional coloring. This gives the dramatic discourse new layers of contextuality that multiply its levels of meaning.

The analysis of Antigone which follows is an examination of this ever-so-subtle background which emerges from a careful reading of these poetic wordplays. Hölderlin reconstructs this backdrop by bringing out echoes of the mythic past and emotions that together constitute the juncture between the logical structures of archaic, pre-classical, "wild thinking" (pensee sauvage, savage mind) and the logic of rational ideas, [End Page 108] norms, and positive law that structure the discursive thinking of the classical polis. $\underline{9}$

Hölderlin's translation at first glance seems extraordinarily perplexing and obscure. But there is an impressive forcefulness in the images he uses to construct certain scenes based on various poetic, mythical references that one would look for in vain in other translations. For example, in the parodos Hölderlin recreates in German a syntax as fluid as the original Greek, whose calculated strategies of blurring the clear rational images produce the impression that Eteocles and Polyneices are not normal human enemies but that they melt into one single hybrid monster--eagle, horse, snake--engaged in a titanic and Bacchic effort of self-destruction. At first, this makes reading Hölderlin's Antigone surprisingly difficult. But it steers the reader's attention toward the truly poetic "nebulousness" of the original text. This "nebulous indeterminacy" brings out the density of meanings in Sophocles' characters and leads one to a progressive awareness of subtly interlocking ethical problems that defy easy answers.

My aim is to show the difference between a conceptually strict categorization (such as that generally attributed to Hegel) which presents Antigone as "the conflict between family and the state" and Hölderlin's "nebulous" density of poetic thought rich with associations, puns, and wordplays that enrich the surface of the poetic text. $\underline{10}$

Through these wordplays each character in the tragedy conveys to the reader/listener at least two different layers of meaning. For the moment, let us lift but one corner of these many layers to get at the issue underlying the ostensible surface conflict of the drama. Beyond the simple question of Polyneices' burial lies the question of whether his death should be honored or not. Antigone believes that it should be because he, like Eteocles, is a philos (friend-relative). Creon, on the 
other hand, argues that this should not be allowed. Polyneices had attacked and almost overthrown the city. Consequently, he is an enemy and as such, deserves no public honors. But Sophocles' poetic ruse is to inject hidden sides to both their arguments. A slight twist of the verbal fabric leads to an imperceptible drift of the reader's mind into hidden layers of meaning. Consequently, the reader is simultaneously reading two different, but not mutually exclusive, versions of a much more complicated story.

For instance, unsettling connotations of eroticism appear in the pious words Antigone utters. The noun philos and adjective phile have the meanings (1) kinship or friendship between blood relations, (2) social friendship, and (3) erotic or sexual love. A single verse, therefore, can express either the pious wish of a character to be morally cherished by [End Page 109] the dead ("I, the beloved, will rest with him, my beloved") or the incestuous, almost necrophiliac desire "I, his lover, will lie down with him, [my] lover." 11 The piety of a young girl facing death under the law for carrying out her brother's burial thus takes on the tinge of a disturbing passion. Up to this point I have only addressed the most common interpretive approach to this tragedy, but let us keep in mind that any explanation which reduces the play's central issue to a question of incestual passion (or, as Bernard Williams says, an almost pathological obsession) risks destroying the beauty and the truly tragic nature of the drama. Aristotle makes the point that a hero is tragic precisely because his fate is inextricably linked to a set of circumstances that make it inevitable, not because he has a particular flaw or vice. With this caution in mind and using Hölderlin's comments on Antigone's matchless beauty and her moving deed, we will try to show the subtle balance between her thoughts and her actions, above and beyond the strictly ethical notions of vice or virtue.

More or less the same phenomenon can be seen working in Creon's "raison d'état," which is "cold" only at first glance. Creon bases his decree on the necessary distinction he makes between "friends" and "enemies" of the polis. But in fact, this distinction does not require the shameful mutilation of a corpse. Ancient Greek customary law dictated that in such a case the body of an enemy was not to be interred with public honors, but should be exposed outside the city walls so that his relatives could come and bury it discretely in an unadorned grave. It is more than a little surprising that Sophocles' Creon (who in Oedipus the King is a character of no particular political

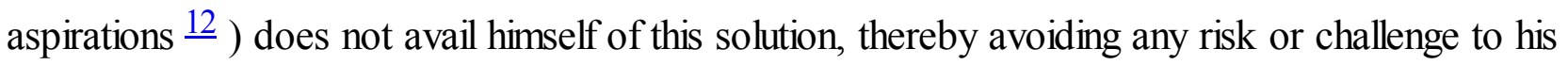
authority, since blood relations had the religious obligation to bury their dead kin.

The strangely vehement behavior of this normally calm character suggests that there is an additional motive behind the openly stated ones. In fact, Creon's decree seems to have a twofold endpoint in mind. Though Creon makes his order apparently to prevent any burial of Polyneices' corpse, this degrading treatment of the dead brother is precisely that which incites Antigone to her fatal transgression. This clever endgame--incomprehensible from the perspective of a peaceful and unambitious ruler--is, however, "reasonable" for a father who wishes to protect his son from a doubly "cursed" marriage. From Creon's standpoint, not only is Antigone the fruit of Jocasta's incestuous marriage, but more importantly, with the death of her brothers, she becomes the epikleros daughter of Oedipus; that is, she assumes a specific legal regime which exceptionally permits that a daughter's future son may prolong his grandfather's lineage, menaced by extinction. $\underline{13}$ This involves a significant personal renunciation for any future husband of [End Page 110] hers, since the man who accepts an epikleros daughter as wife gives over his own posterity to the continuation of his father-in-law's lineage. Before going into detail about what this implies symbolically, materially, and psychologically for Creon himself, there is another issue to consider-the public interest motive behind Creon's prevention of this marriage. Haemon is not only a first cousin of Antigone but, because of Jocasta's incestuous marriage, triply related to Antigone as 
cousin, uncle, and nephew. In the Prologue this triple stigma is given as the cause of the fall of the house of Labdacus and it is this sort of moral flaw that Creon is referring to when he explains that his supreme concern is to put an end to the disastrous disturbances caused by those who cannot distinguish between "friends" and "enemies" (L 187ff.). Here Creon is subliminally alluding to the calamities brought down upon the city through the fatal embodiment of friends-relatives (philoi) and civic enemies in Oedipus's offspring (although Creon plainly makes light of this in regard to Haemon).

These various character insights just barely rise to a level of conscious perception, brought out by the interplay of Sophocles' finely tuned metaphors and wordplays. Hölderlin uses changes in the tone of his translation to convey the emotional ambivalence that dominates the conversations between Antigone and Ismene. This technique allows him to express the finesse of Ismene's words in the verses where she advises her sister to keep her plan to bury Polyneices absolutely secret: " [Go] if you wish. But let nobody hear of your feat! Be secret! So I can be with you / take part in it" ["Meinetwegen. Lass die That nur niemand hören! Halt dich jezt still! So kann ich mit dabei seyn"] (L 84 s., H 86 s.). This translation brings out nothing more than the fear of legal consequences from carrying out the burial. Sophocles' original Greek, however, encompasses three different connotations in the final words of this verse ("I will help you") that prefigure the turning point (metabolê) of the tragedy. An emendation suggested by the Laurentianus manuscript scholiast captures the homophony of sy (you) and syn (you and I together, we), suggesting the incestuous community of Antigone's family. Dimly hinting at the terrible truth which Antigone will later discover (namely, her own involvement in the curse weighing upon Thebes [L 800ff.]), this "I will help you" signifies both: "You and I [we are] the same [blood]" and, as if this allusion to their accursed lineage were not enough: "You and I, [we are] in vain." To make this last meaning even clearer, all the actor has to do is to say the words with a slight sigh of hopelessness. $\underline{14}$

By changing the tone of his translation, Hölderlin weaves a web of fluctuating emotions into the dialogue between the two sisters (and other characters as well). By turns, Antigone is both impassioned and [End Page 111] calm, haughty and tender; provoked to anger, she becomes sweet and loving again when Ismene insists on sharing her fate. Likewise, Ismene does not remain the picture of feminine submissiveness, but shows remarkable signs of courage and insight amidst her fear and confusion. And so, we see in those verses spoken by a seemingly minor character an almost prophetic utterance encompassing the entire fatal tragedy of Antigone and her lineage. The truth that the heroine will discover is not that she is unjustly condemned, despite the injustice of Creon's decree and her ultimate condemnation. What her own insight and perception reveals to her is the unfathomable depths of her own desire and will. Antigone comes to the realization that her conscious desire--however noble and sacred--is inextricably linked to an even deeper, ancestral impulse. Her bravery in carrying out her sacred duty is overlaid with the incestuous impulse found in all the leading characters of her family. Blood being thicker than water, in matters of love and matrimony everyone puts the members of their own family above all else: "you and I, we are one."

This being-drawn-toward-one's-own (blood) means that this lineage lives, grows and reproduces "in vain": "you and I, we are in vain." The mythology surrounding this house shows, time and again, how its heroes get mixed up in incestuous flaws while trying to avoid their own miserable, wretched inclination. Oedipus is both son and husband of his mother; Jocasta, both mother and wife of her son; Antigone, daughter and granddaughter of her mother, daughter and sister of her father, cousin, niece, and aunt of her betrothed! Being all things, she loses her own identity. Succeeding generations also seem to go backwards as they advance in time: granddaughter is 
daughter, daughter is sister, everything is endogamic, "turned inwards" to incestuous sameness: the lack of identity which comes up to being "in vain."

Looking closer, we see that from the very beginning incestual tendency to sameness haunts and bedevils the very foundation heroes of Thebes. The Thebans were descended from the spartoi, men who were born from dragon's teeth sown in the earth. They were born without father or mother to teach them the customary ways of human conduct and feelings and are irresistibly drawn to each other. Their defiant confrontation of each other (neikos signifies a competitive act) leads to fighting and mutual extermination. $\underline{15}$ This is exactly how Polyneices (Polneikos) and Eteocles bring an end to Thebes's most famous lineage as Ismene reminds her sister in the prologue: " [Consider] In the third place / The two brothers, who, within One day / caused parental death through enemies' hands" ["(Bedenke) Zum dritten / Die beiden Brüder, die an Einem Tage / Verwandten Tod mit Gegnerhand bewirket"] (L 55, H 57). Hölderlin's translation evokes this mythic context in a remarkably [End Page 112] striking manner which both reinforces and enriches the tragedy of Sophocles' drama. This depth of poetic signification (or thought) raises issues that go beyond the apparently simple ethical interpretation of the play in Hegel's "classical" categorization in Phenomenology of Spirit, where he maintains that a truly ethical conflict presupposes sincere honesty. $\underline{16}$

Hegel's simple observation brings up a "detail" in the drama that has drawn surprisingly little attention. It is hard to deny that Creon's strangely obstinate enforcement of his decree is an honest example of sincere conviction. In it there is neither the crafty cynicism of a coldly Machiavellian tyrant nor the Stoic patience of an "enlightened" despot. However, as noted above, this persistence must have deeper roots than the simple political reasoning of a ruler. The death of both Eteocles and Polyneices (without offspring in Sophocles' version of the story) juxtaposes the problem of the welfare of the state and the welfare of Creon's own family. If Eteocles had begotten an heir (whether a son or daughter) Antigone would not be placed in the position of an epikleros daughter (that is, "one who follows the kleros of her father"). She and Ismene being the only surviving members of their house, the institution of the epikleros ensures the perpetuation of their lineage by enabling a daughter to transmit the succession to the throne of Thebes to any future son. In the circumstances surrounding the death of the two brothers, Creon suddenly sees a situation arise where his political and religious concerns for the welfare of the State as regent coincide with those as father for his last surviving son.

In this mythic world the "peace" which settles on Thebes after the death of the two brothers is not a promising one. It is both the peace of the conquered and the peace of the conqueror. Thebes has repulsed the enemy army but has lost its own leader as well as his brother: an enemy (anêr dysmenês [L 187, H 192]) who is also a friend (philos). A pall lies over the celebration and there is nothing to prevent the Thebans from "freely associating" and seeing a sign of divine wrath in this equivocal victory. Creon uses this rationale in his first speech justifying his decree, with a logic that is diametrically opposed to that of the Chorus in the opening hymn. Hölderlin evokes all the gravity with which the elders of Thebes speak of this war--which has only ended the night before!--as if it were a far-off battle of titans or a tale from Hesiod, and whose protagonists can be seen, thanks to the narrative "distance," as daimones who will henceforth watch over the city with divine benevolence. Creon, on the other hand, sees the war realistically and pragmatically in the here and now, a fratricidal event which has brought on a religious pollution that must be purified. And although it is Creon who comes up with and makes use of this reasoning, his fateful logic of miasma and the fears it provokes are a danger to the peace and well-being of Thebes. [End Page 113] This danger might well explain why Creon lays out the reason for his decree with such 
vehemence, reducing an exceedingly complex problem to a very simple form of categorization. $\frac{17}{17}$ Unlike the rationale in the ancient myths which passed no judgment on the rights or wrongs of the two sides in the Theban conflict, Creon proposes a seemingly clear standard of judgment: "If on this soil / homeland there is a [person] discontent, / [I will not] have him as my friend" ["Wenn auf dem Grund hier ein Verdrossner ist, / ("werd" ich nicht) Den mir zum Freunde machen"] (L 187, H 194 s.). But in Greek this sentence expresses more than just a commonplace distinction between friend and enemy status. One's "country," chthôn, is not only one's political homeland but above all one's Motherland. As we know, in Thebes all the descendants of the spartoi shared the stain of their all-too-natural origins and thus in human origins were part of this one-and-the-sameness: they were all friends-enemies, sons-brothers, espoused-annulled, sons-husbands, sons-grandsons. Sophocles makes explicit reference to this confusion when he calls Polyneices "he who came amphilogon" (L 111)--that is, as an ambiguous sort of relative-friend-enemy, just like Eteocles who should have ceded power at the end of the prescribed year but who became an anêr dysmenês: a man who confronts, a friend-enemy rivaling his own brother. $\underline{18}$

Creon, who unwillingly took on the burden of the state, correctly identifies these incestuous entanglements as the cause of the city's inescapable miseries. And as he ponders his city's wretched history he is forced to the unavoidable conclusion that the marriage of Antigone (epikleros daughter and potential mother of an eventual heir to the throne) with Haemon (her own cousin-nephew-uncle) would only bring about the ultimate interbreeding of the ancestral and descendant branches of this family tree. It would take a calculated effort to list all the overlapping degrees of kinship that the son of such a consanguineous marriage would embody. Any such child would be simultaneously grand-nephew, uncle, and cousin several times over of his own parents.

No father could honestly wish for his son to beget children with such a monstrous heritage. And no leader with any concern for royal, symbolic order could permit such an unsettling marriage to take place. From a psychological point of view, the subtlety with which Sophocles ties together all these issues is extraordinary. The more Creon ponders the possible causes of Thebes's misfortune and the more he seeks a solution that will benefit the state, the more he is led to a horrible understanding of the depth of disaster that awaits his son Haemon on a political, familial, and personal level. In this context the "cold" resolve with which Creon enforces his decree precisely reflects what Hegel calls the "tyrant's sacrilege," the crime of a foundation hero for whom the [End Page 114] only possibility of reestablishing human, social, and political order is to make a break with the former habits of Oedipus's descendants.

What Creon does not realize (though one can hardly blame him for his all-too-human lack of insight) is that while escaping the curse of Oedipus's family, Thebes and Haemon still lie under the burden of another primordial curse: the inhuman, purely natural evolution of their ancestors, the "spartoi." All the descendants of these men who were born directly from Mother-Earth find themselves under the overwhelming ascendancy of the feminine. Their one-sided, fatherless genesis means that the men of Thebes always swing abruptly from a fatal attraction to their mother to a negating neglect of their wives.

The spartoi, those sons of an omnipresent mother, do away with each other so that they might return as quickly as possible to Mother-Earth, thus fulfilling to the letter the words of old Silenus. Labdacus symbolically does away with himself when he turns power over to his mother's brothers. And on another limb of the family tree, the story of Pentheus presents a variation on this theme. Intent on putting an end to the wild disorder of the Bacchantes disturbing his city, he unwittingly espies his own mother and is torn to pieces by her. Similarly, Oedipus makes a return to Jocasta's 
womb in his attempt to resurrect the city of Thebes.

In Oedipus's case, discovery of the mother annuls the very existence of the wife. In Pentheus's case, his complete self-absorption in the single-minded pursuit of the Bacchantes betrays a peculiar absence of wife, sons, or grandsons. The same is true of Laius who is consumed by his homosexual passion for Chrysippe, while Eteocles is conspicuous in his disdain of women and in his efforts to create an exclusively masculine, virile city.

This emotional confusion reflects an anomaly in the transfer of power which is mirrored in the logical confusion of the succession. Time seems to stand still, moving forward and backward simultaneously, in that each succeeding ruler is both an ancestral and a descendant branch on the family tree. Simultaneously "anterior" and "posterior" to his own era, both "within" and "without" his own identity, each and every Theban merges with each other and are all "the same" and all "in vain."

Tiresias and Creon are prime examples of this confusion and play disquieting and "unnatural" roles in the Theban cycle. They are omnipresent throughout the cycle from beginning to end--an omnipresence that defies all logic of human time which is normally restricted to a range of one to three generations. Creon surfaces time and again during various points in the story both before and after his proper generational time period. Similarly, Tiresias appears at all stages in the myth in an "irrational" and inexplicable lifespan that encompasses the [End Page 115] founding era of Cadmus to beyond the death of Leodamas and the destruction of Thebes. This unusual livingbeyond-oneself captures in a mythic and narrative way the excessive, un-human and almost unnatural being of the Thebans. Their progenitors' unnaturalness reappears in later generations like a genetic flaw, creating a defective or excessive ordering of time and space and a confusion of male and female.

Not only Polyneices, but everyone in Thebes is amphilogos, ambiguous, double--that is to say, both more and less than what they are: in an infinity that conflates and equalizes everything. Time expands and contracts uncontrollably. Mothers become wives; daughters become sisters. Tiresias is transformed into a woman and becomes more than a man. But he is also more than a god. He comes to know the pleasures and delights of both man and woman, making even the gods jealous. $\underline{19}$

And so, the cunning web in which Creon entraps Antigone is "nothing more" than an all-too-human attempt to avoid an even greater disaster: the miasma (pollution) and utter destruction of Thebes. A number of quantitative and qualitative aspects shape and inform this secondary subplot that is played out on levels of the heart and of politics. One of these emerges in the surprisingly long dialogue with the Guard that extends, with only a brief interruption by the Chorus, from verse 230 to verse 457 in the Belles Lettres edition.

A reader/listener who is either unaware of or has forgotten the complexities of the Theban genealogy will probably only be conscious of the somewhat "angular," disjointed, and almost clumsy exchange of words between Creon, the Guard, and Antigone. And frequently, even this can pass unnoticed in translation. Nevertheless, if one recalls the dismal story of Thebes's primal miasma, the double meanings of the Guard's and Creon's words will be easily noticed and the "angularity" of the text will be seen as hints at things left unsaid and hidden messages.

Many critics have remarked upon this conversation between Creon and the Guard, its surprisingly informal, familiar tone, and the stylistic drift of the king's speech into a more popular manner of 
speaking. But this affinity of the king with a common soldier might also reflect an underlying and somewhat sordid complicity engendered by the twofold endgame of Creon's decree. Let us take a look at a few of the innuendos made by the protagonists that secretly refer to the suppressed but recognized fact that the decree's aim is, in truth, the extermination of Oedipus's polluted lineage.

The Guard arrives convinced that he will be put to death, since none of his companions, who each suspect the other, have been able to explain the mysterious burial. To his surprise, Creon does not suspect any of the guards of being the author of the crime, but lets it be known that he considers them the contingent instruments of another who [End Page 116] interests him even more, to the point that he forgets the exact wording of his decree stipulating death for whoever dares bury the body. After a few clever interchanges it is clear that the not-so-"simple" Guard quickly sees that he is not under suspicion himself. During the dialogue he comes to a perfectly clear realization that the "guilty ones," as far as the law is directly concerned, are the surviving descendants of Oedipus: Antigone and/or Ismene, preferably both.

Anxious to condemn the "guilty parties," Creon insinuates threateningly that he might hold the Guard on charges of being corrupted by the two sisters if he does not hand them over. Hölderlin's translation of this passage sensitively underscores the "criminal" tone of the interchange between Creon and the Guard:

And so you'll see how to get your share, How plunder be taken, and so you'll learn

That not everything is made for gain.

For mark me well, ill-gotten gain has

swindled more than those who've profited by it.

The Guard is astonished at not being arrested, accused, or put to death. He seems to comprehend very quickly Creon's hidden agenda and gives a prompt and ambiguous answer: "Is that an order, or should I go?" (H 331). Conversely, Creon sees that his plan has been understood by the Guard and replies: "Don't you know what agony there is in your words?" The Guard replies with a touch of insolence: "Does that sting your ear or sting your heart?" Creon answers this insolence with the unfeigned anguish of a man who sees himself backed into a corner by Fate and who knows that there is no happy way out of this impasse: "Why are you concerned with my anguish?"--which also means--"Who are you to know anything of my anguish?"--or "What can you know of my anguish?" This refers, of course, to the tremendous sorrow he feels as father and as king that he is practically impotent to bring any happiness or good fortune to his city or his son. But the Guard now sees his advantage in this unwitting collusion and cannot resist an inferior's pleasure in his proletarian insight: "The guilty one tortures your mind, I [only] your ears." Creon slowly "recovers" from his anguished ruminations and is struck by the Guard's malicious truths, yet makes no rebuke for his insolence: "O my [God]! What a terrible language you were born for!" Only when the Guard remarks with an even more pointed degree of insolence and callousness-- "That's because it doesn't have anything to do with me."--does Creon come to himself and resume his accusing threat of blackmail: "But you are! [On the charge of] selling your soul [End Page 117] for money!" This first part of the dialogue closes with the Guard's comments in which we see the workings of a keenly observant mind, of a subordinate who is half-surprised, half-inured to the intrigues of his betters.

After the celebrated "hymn to the deina," the Guard returns with the same half-cynical, half- 
bemused humor of someone who is at once an outsider to the drama of which he is a part and yet thoroughly accustomed to the internal logic of this game of appearances. Basically indifferent to it all, he feels no qualms in making light of the tragic turn the drama is taking. He comes in with the shrewd observation that by capturing Antigone his fate has swung around to something surprisingly gratifying (H 408 s., L 392 s.). With the same tone of familiarity used by an underling who has hit upon the weakness of his master, he addresses Creon without any veneer of ceremony or deference and with startling candor as to the king's entire scheme: "She's the one who buried the dead man. You know everything" ["Die hat den Mann begraben. Alles weist du"] (L 402, H 418). The Guard literally spells out that Creon already knew the offender. Creon understands what the Guard is aiming at and adroitly steers the conversation in another direction: "Do you know what you're talking about?" ["Weist du und sagst auch recht, was du geredet?"] (L 403, H 419). This could mean either "Do you know who you're accusing? [that is, a princess]" or "Hold your insolent tongue and never reveal what you know [that is, that she's the one I was looking for]." The Guard makes one last equivocal reply before dropping back into the more formal, investigative demeanor that Creon has imposed upon their conversation: "She's the one I saw burying the dead man against your orders. Is that clear, or what?" ["Begragen sah ich die den Todten, wo du es / verboten. Hinterbring ich klares, deutlichs?"] (L 404, H 420). It is as if this subordinate, feeling comfortable in his sense of complicity and indifferent to the ethical or juridical merits of the case in question, is saying: "What's the matter? Why so formal? Everybody knows she did it and that she's the one you're after! What more do you want?"

After this last insolence, the Guard falls back into a formal recitation of the facts, which Antigone later freely confirms when interrogated by Creon. The interrogation gives Creon two different avenues of accusation. The first lies in the formal charge against her--Antigone has violated the established law (L 481, H 500). This offense would in itself be suffi-cient to condemn her to death. But Creon, who was so patient with the Guard's insolence, takes great pains to point out the supposed insolence in Antigone's responses. Antigone punctures the hollowness and falsity of Creon's indignation when she asks with a mixture of irony and [End Page 118] sadness: "You have me in your grasp: do you want more than my death?" ["Willst du denn mehr, da du mich hast, als tödten?"] (L 497, H 518).

Creon's affected anger is, in fact, more of a setup to distract attention from what he is really aiming at--which is the absolutely baseless condemnation of Antigone's sister, Ismene, who has been implicated in neither the Guard's story nor in Antigone's confession. Looked at formalistically, Creon's anger does furnish a psychological pretext for his logical non sequitur. When Creon and the Guard were discussing Antigone's crime there was no mention of any other suspect. Creon could not have implicated Ismene by means of a dispassionate investigation of the facts. His heated outburst, however, serves to cloud the issue and hide the weakness of his case when he suddenly turns upon Ismene, saying that he saw her "out of her mind" (H 523, L 492)--which is highly improbable since Ismene herself expressed the utmost desire to keep her sister's plan secret.

Seen this way, Creon really does want more than Antigone's death. What he wants is the end of this family miasma--a wish that Antigone picked up on with her question: "Do you want more than my death?" And yet, this is not a "desire" in the normal sense of the word. Creon's response to Antigone "speaks volumes" about the silent (and vain) struggle he has undertaken against Thebes's plight and he answers with a rhetorical denial: "Not at all. With that alone [your death], I have all [that I want]" (L 498), or, in Hölderlin's version: "I want nothing. When I have it, I'll have everything" ["Nichts will ich. Hab' ich diß, so hab' ich Alles"] (H 519). Creon has gambled "all or nothing" in his attempt to save both Thebes and his son. He recognizes that in this no-win situation 
he must give up any thought of personal happiness. It is no longer a question of any particular wish or desire, but of winning or losing everything. Creon believes that by eliminating Oedipus's last descendants, he will also put an end to the polluting stigma of incest. His fatal error is not realizing that in Thebes, this means "Everything." In a city of such "indistinguishability" everything and nothing "comes to the same thing." Creon fails to see that Oedipus's incest is not the cause of the miasma, but the consequence of an originary pollution. This incestuous calamity is only the latest blossoming of the original confused and "undifferentiated" procreation of the fatherless spartoi from the maternal element alone.

By trying to avoid disaster Creon, like Oedipus, will only "see" it after it has already occurred. This is the main point that destroys the close parallelism between Creon and Antigone. She, on the other hand, eventually comes to a complete understanding of the logic of her own heroic suffering. After her heated conversations with Ismene and Creon, [End Page 119] Sophocles portrays Antigone in a moment of reflection. She goes over in her mind the ancient stories and images. Distant figures and old tales fill her imagination and in them she tries to find something of her own destiny. It is in this intuitive state where the logic of imagery and narrative (not of juridical ideas or concepts) prevails that Antigone sees the connection between her own (literally) incestual origin and the (figuratively) incestual origin of all Thebes. Antigone's intuitive meanderings have an implacable logic and rigor that mark her superiority over Creon, despite the surface symmetry that Hegel observed. Her mental journey begins with a self-identification with Niobe (Thebes's most fertile and most sterile progenitor, a mother who gave both life and death to her offspring). She then passes on to an identification with her own parents, who both did and did not have children in the sense that these children were also sisters and brothers or grandchildren. Out of this comes an awareness of self which remains halfway between the "unspeakable" and the "speakable" in that it remains figurative. This "re-cognition" allows Antigone to atone for the miasma through the suffering she undergoes by her own self-signification and in that interiorized sense she dies freed of it. Hölderlin stretches the traditional reading of Sophocles' text a bit by stressing the oracular insight of the Chorus's words when they take up Antigone's own musings: "It destroyed you, the wrathful self-recognition" ["Dich hat verderbt / Das zornige Selbsterkennen"] in place of a more traditional translation: "Your own passion, in its self-absorption, has caused your downfall" (L 874, H 905). The word "passion" is a translation of the Greek word orgê (humor, aspiration, ambition, passion, rage). In this verse it is in its dialect form, orga, which to Athenians had clearly sexual connotations of orgasmic passion. In this context--Antigone's discovery of her own place in this incestuous "auto-engendering" (autogennet' [L 863, H 894])--the verse clearly refers to her awareness that the fate of previous generations of Labdacides is now befalling her. However, in the mouths of the Theban elders this mental association between sexual passion and the impassioned search for the beautiful, for law and social order that enables man to live in a civilized fashion, is suggested in two ways.

In its recounting of the awe-inspiring "wonders" of mankind, the hymn to the deina pays homage to the great founding "acts" of civilization. The Theban elders use the same word, orgas, in a grammatically ambiguous position which blends the idea of unbridled sexual passion with the civilizing impulse (orgê-orgas): "And the speech and the airy / Thought and the pride to govern cities / He learned" ["Und die Red'und den luftigen / Gedanken und städtebeherrschenden Stolz / Hat erlernet er"] (astynómous orgas edidaxato [L 354 s., H 371ff.]). Hölderlin seems to have realized that Sophocles is availing himself of [End Page 120] the inherent association between the idea of orgê/humor and that of orgas/sexual passion to imply that cultural aspirations are forever bound up with the orgiastic, sexual impulse. Beneath the "desire for civic order"--the praiseworthy goal of all properly ordered human civilization (städtbeherrschender Stolz [H 372])--resonates 
the destructive undercurrent of orgas(m). When Antigone realizes this, it sets her own mind reeling ( $\mathrm{H} 877 \mathrm{ff}$.). And it is the Chorus's words that draw the heroine's attention to the scandalous parallels between the "great feats" of Thebes's origins and the unspeakable sexual crimes which transgressed the laws of human generation. The Theban elders address Antigone in an unusual way: "Oh child, you fell low, / However, you die for fatherly feats" ["Bist du, o Kind, wohl tiefgefallen, / Stirbst aber väterlichen Kampf'] (L 856, H 885 s.). Athleô--to work, labor, fight, conquer--has essentially physical and athletic connotations. The ambiguous genitive construct "It is your fathers' feats" can mean "for your fathers' feats" as well as "because of your fathers' feats." In either case, the words link Antigone's "personal" wrongdoing to a preexisting inevitability and to a continuum above and beyond the actions of any individual. The range of metaphorical associations informing the lexical construct "fathers' feats" (patrôn athlon) must be considered in order to understand the full ramifications of this verse. The derivations of athl- (athlêtês, athleô, and so forth) relate, in various mythic contexts, to the "athletic" conquest of a wife, a territory, or kingdom leading to the establishment of a settled, agrarian society. 21 "Athlete," in this sense, signifies not only the warrior-athlete, but also the "knowing sower" (habile semeur) $\underline{22}$ who generates life from the maternal womb (mother-earth). In referring to Thebes this way the Chorus hints at this fundamental Theban archetype. Two father figures are specifically implied: Cadmus and Oedipus, the beginning and the end of this lineage--who, in fact, are both "prodigious farmers" (athletes deinotas). Both are "tricksters," progenitors who go beyond the limits of customary human procreation. Their insemination of the maternal womb (with Cadmus, the earth itself; with Oedipus, his own mother) results in "the same"--men such as the spartoi or Eteocles and Polyneices. The very name "Poly-neikos" accentuates the paradox of neikos (hate) being injected into the midst of philia (friendship, kinship) and the idea of aversion within the family unit. In this incestuous family, love (philia) mingles with hate and contention (neikos). The good Eteocles and the bad Polyneices complement each other and effect a kind of reunification through their confrontation. They meet and fight as kin (philoi) who are also enemies (andres dysmenai). The "sons" born of Cadmus "sowings," united in deadly kinship, are reborn in the sons of Oedipus who also tear each other to pieces. And if this mythic context were not enough, Sophocles strengthens the confusion of agricultural [End Page 121] and sexual metaphors by putting the traditional Athenian matrimonial phrase directly into Creon's mouth: "[For Haemon] there are other fields to plough" (L 569) $\underline{23}$ implying that Haemon should marry a woman outside of his own lineage. $\underline{24}$

Through multiple metaphorical associations Antigone comes to see the analogy between her own action and those of her family's "paternal feats." Her burial of her brother is, like other attempts to uphold or reestablish human civilization at Thebes, amphilogon, doubly motivated. On the one hand pious and laudable, her burial of her brother is, on the other hand, scandalous by its passionate and incestuous nature. It is an act of love that does not lead to new life, but to a shared death. It recalls Oedipus's own fears that prodded him to return to his Theban homeland and to his own mother, to the orgas of an incestuous bed, that Antigone now associates with these fatal "paternal feats." As soon as the Chorus utters the words patrôn athlon, Antigone is stricken with dismay and cries:

You have struck the most painful

Of my endless woes,

The oft-repeated father's lament

And the whole

Of our fate

We glorious Labdacides. 
Io! You mother's-madness

In whose embraces, from the self-begetting bed

Of my father and unfortunate mother,

From thence I came, miserable

(H 886-93, L 856ff.) $\underline{25}$

Antigone has achieved a level of complete self-awareness and has reached the highest state of nobility--in both the ethical and political sense--of her entire family. She now stands at the edge of the terrifying abyss of nothingness. But instead of collapsing under the terrible truth that she is the unspeakable fruit of incest, she does utter it and thereby constrains it. Her utterance is recognition, anagnôrisis, in the Aristotelian sense of the word, grasping the true essence of her being. The chorus responds to her admission with another ambiguous phrase. Torn between admiration and horror, the elders return to the same oblique and equivocal use of the word orgê-orgas that we saw in the hymn to the deina: [End Page 122]

Your passion made known through itself has destroyed you.

Your passion made known to itself has destroyed you.

[Sé d'autognôtos ôles orga.]

(L 875, H 905 s.)

Antigone realizes--at least in Hölderlin's translation and in Hegel's interpretation (which could have been influenced by Hölderlin's translation)--that the restless drive for civilization, knowledge, and humanity is driven by a passionate and carnal impulse. She also sees that the "innocent" decency and devotion that compelled her to bury her brother were grafted onto a disturbing passion and that without this passion there is no goodness, no desire, no knowledge. Having comprehended this paradox, she dies not so much by Creon's hand, but by her own. In this light, Hölderlin's translation invests the heroine's suicide with a deeper, richer meaning that did not exist in the mythic tradition before Sophocles.

By carrying out her brother's burial, Antigone upholds the beauty and nobility of her family against the downfall which enables Creon to substitute his own lineage for that of the Labdacides. The political and religious drama, however, is also played out on a metaphysical plane. In the drama Antigone starts out as an epikleros daughter who defends the honor and very existence of her family with the ultimate sacrifice. By her own actions she faces up to the very nature of her being and that of all her ancestors (even if this being is "openly-hidden" to the knowing eye)--that is, the unspeakableness of absolute nothingness. Hölderlin expresses this tension in the drama in a remarkable way. Antigone's self-identification with her ancestors (Niobe, Oedipus) reveals to her both the greatness and the "nothing" that they all are. In the recognition scene with the Chorus Hölderlin expresses (with even greater clarity than Heidegger's analysis of the hymn to the deina) this oneness of being and non-being. This scene uniquely illustrates the interpretation that Heidegger weaves around the concept of Greek "thought," the pre-Socratic noein. Antigone does not "think" in the modern sense; she does not reflect upon a specific object. Rather, she "recognizes" and "understands" in the sense that she hears and reflects (vernehmen, Vernehmung), embracing (hinnehmend) what her senses have taken in (Vor-nehmen) and what is present but hidden in her own mind. The word autognotos which Hölderlin translates as "Selbsterkennen" corresponds exactly to the configuration which Heidegger analyses in the noein of Parmenides: apprehension as the embracing register [within which] the being is opened up and thus comes forth into disclosedness ("Vernehmung als das hinnehmnde Vor-nehmen [in der] 
das Seiende als solches aufgeschlossen wird und so in die Unverborgenheit her-vorkommt"). $\underline{26}$ In other words, perception [End Page 123] supposes an "embracing register," a logical foundation previous to positive knowledge; that is, "apprehension" as a simultaneously sensitive and intellectual operation (an act of grasping), within which things are and become comprehensible to us.

The determination of this pre-Socratic thought within the realm of the poetic suggests a connection between paragraph forty-nine of Kant's Critique of Judgment and chapter six of Aristotle's Poetics. 27 Kant maintains, in effect, that aesthetic expression consists of a richness of interconnected thoughts (we would say associations) that amplify an idea but whose very multiplicity prevents their clear representation within a single philosophical concept. Kant's "aesthetic idea" thus refers to a kind of nebulous signifier "enveloping" a conceptual axis but irreducible to it.

Aristotle touches obliquely upon a similar notion in the Poetics. In chapter six he distinguishes between character/ethos (the fixed, unchangeable temper of a person from an ethical point of view) and the aesthetic character of the hero in poetic representation. Aristotle stresses that the tragic hero is not an example of a clearly defined ethical category. Rather, the poetic persona is built up within an interwoven network of discrete, individual actions: "it is through actions that characters are drawn (symperilambanousin)." $\underline{28}$ In other words: discursive concepts fall short of poetical meaning because tragic poetry is a "metaphor of the intellectual intuition"--a glimpse of the overall cohesiveness of the manyfold and seemingly incoherent actions which "gravitate around" and "embrace" (symperilambanousin) an invisible axis: the tragic hero.

\section{Universidade Federal do Rio Grande do sul}

(Translated from the French by Edward J. Shephard, Jr.)

Katherin H. Rosenfield is Assistant Professor at the Department of Philosophy of the Federal University of Rio Grande do Sul, Porto Alegre, Brazil. She has published books on French medieval literature, on Brazilian literature, on German Romanticism, and on T. S. Eliot. She is currently writing a book on "Holderlin's Sophocles."

\section{Notes}

1. See Johann Christian Friederich Hölderlin, Sämtliche Werke, "Frankfurter Ausgabe," ed. D. E. Sattler, vol. 16 (Stroemfeld/Roter Stern, 1988); hereafter cited in text as H and followed by verse number. This translation is available in a bilingual (German-French) edition by Philippe LacoueLabarthe published by Christian Bourgeois (Paris, 1978). References will also be made to Paul Mazon's French translation of the Antigone, also known as the Belles Lettres edition (Paris, 1997); hereafter cited in text as L and followed by verse number. The abbreviation KStA refers to the "Kleine Stuttgarter Ausgabe" edition of Hölderlin's Sämtliche Werke, 6 vols. (Stuttgart, 1965).

2. Dieter Henrich has demonstrated the importance of Hölderlin's philosophical thinking on German idealism and the influence it had on Hegel and Schelling. See Dieter Henrich, Der Grund im Bewusstsein. Untersuchungen zu Hölderlins Denken (1794-1795) (Stuttgart, 1992). See also The Course of Remembrance and other Essays on Hölderlin, edited by Eckart Förster (Stanford, 1997). 
3. The review has been reproduced in the "Frankfurter Ausgabe" of Friedrich Hölderlin, Sämtliche Werke, 16:20-25.

4. See Kathrin Rosenfield, "Control through the Imaginary: Ancient Poetics and Modern Thought," in Masks of Mimesis: The Work of Luiz Costa Lima, ed. Ivo Barbieri and João Cesar de Castro Rocha (Stanford University Press, forthcoming).

5. On Goethe's influence over Hölderlin, see Eckart Förster, "To Lend Wings to Physics Once Again: Hölderlin and the 'Oldest System-Programme of German Idealism,'" European Journal of Philosophy, 3, no. 2 (August, 1995), 174-200.

6. See Immanuel Kant, Kritik der Urteilskraft (Frankfurt am Main, 1997). See also Eckart Förster's observations, in "To Lend Wings to Physics Once Again," on Hölderlin's plan to critique the aesthetics of Schiller's Kantianism in his "New Letters on Aesthetic Education." See also Henrich's remarks, in Der Grund im Bewusstsein, on "going beyond Kant" (pp. 158ff.)

7. In a letter to Niethammer of 24 Feb. 1796, he outlines a justification of the idea of liberty as a condition and "principle of the distinction by which we think and exist," an "intellectual intuition" that does not depend on practical reason. In his fragmentary "On the Law of Freedom," Hölderlin sets out this formulation through imagery conveying a deep sense of similarity between the imagination and moral law. He conceives a hypothetical state prior to all knowledge and all consciousness in which there exists, in a contingent manner, a complete conformity between the "natural state of the imagination," "appetition" (longing desire) and "moral law." See "Kleine Stuttgarter Ausgabe," Sämtlichewerke, 6:219 and 223. This intuitive grasp of the complete anteriority and independence of the practical is at the heart of the philosophical fragments and correspondence of the years 1794-96.

8. See the observations of Henrich, Der Grund im Bewusstsein, p. 519, regarding the theoretical bases of Hölderlin's thinking. Although he does not mention Hölderlin's working his way back from Kant to Aristotle and the notion of kalokagathia, Henrich emphasizes that there is no "theoretically illegitimate violation" in the linkage Hölderlin makes between "cognitive selfknowledge (wissendes Selbstverhältnis) and the innate modes of cognition that continue to resonate with affective impress."

9. I have discussed the ties between Lévi-Strauss' The Savage Mind, kalokagathia, and Aristotle's Poetics in my "Control through the Imaginary" (see note 4).

10. And also to demonstrate that the Hegelian "categorization" is not quite so simple and that several passages in the Phänomenologie des Geisters (Frankfurt, 1970) that have no obviously direct link with Sophocles' Antigone do, in fact, address the plethora of ideas subsumed under the notion of the aesthetic idea (see note 16 regarding "sincere honesty").

11. This idea of Antigone's incestual tendencies has been noted by several critics, among them Seth Benardete, Jacques Lacan, Nicole Loraux, Martha Nussbaum, Pierre Vidal-Naquet, and Bernard Williams. What I am interested in is not determining whether these tendencies really do exist, but rather determining what relationship exists between this inherent emotional stigma and the ability of the mind to free itself of emotional determination. It is precisely in the transition from empirical knowledge to the free play of reason that the parallelism between Antigone and Creon which Hegel pointed out breaks down. 
12. See Creon's self-defense against accusations that he plotted against Oedipus where he points to his supposed preference to remain comfortably in the shadows of power.

\section{See Pauly-Wissowa, Lexikon der Antike in fünf Bänden (Munich, 1979), "Epiklerat."}

Jean-Pierre Vernant, Mythe et Pensée, I, p. 144, defines the term epikleros as "[a daughter] who follows the kleros of her father." The function of the epikleros is to assure the survival of the paternal house (oikos). "[In an epikleros union] the purpose is not so much the collateral transmission of an inheritance as it is the continued existence, through the daughter, of the household. From this point of view, the marriage of a relative with the epikleros daughter is not so much a prior right of inheritance as it is a familial duty that meant a real renunciation on the part of the intended husband: a son of such a marriage would, in fact, be continuing not his father's lineage but his maternal grandfather's" (I:145).

This provides another reason (above and beyond the political one) for Creon's objection to his son's marriage with Antigone, which he calls "a cold embrace"; it also explains why he is so obsessed with the idea of male subjection to the female: in an epikleros marriage, the normal matrimonial relationship is reversed. "In it the woman represents the fixed element [the perpetuation of the oikos] and the man, the changing one. .. . Henceforth, the wife, as daughter of the house, is the paternal household" (I:146).

14. The Belles Lettres edition of the text has "syn d'hautôs egô." "[S]yn" being in an adverbial position (see Liddell and Scott's Great-English Lexicon [Oxford, 1996]) gives the meaning "I will help you." The problem is that, in this usage, the sun comes from a tmesis and requires a verb (see Ajax v. 1288 "and I was there [too/with]"). Since the verb is lacking, the Laurentianos scholiast emended the text to: "su d'hautôs egô." This version permits the reading: "you and I, the same" or "you and $\mathrm{I}$, in vain," since autos can have both these meanings. "[A]utôs" can be spoken poetically with a sustained aspiration, thereby giving the actor the ability to imply the sense of despair of vanitas.

In any case, sy and syn are so close phonetically that the three different meanings are implied anyway, no matter which manuscript tradition is philologically correct. This works in the same way as Baudelaire's famous line "Je suis le roi d'un pays pluvieux" where the double entendre of the homophonic pluvieux-plus vieux is clearly understood within the generally decadent tone of the poem even if, from a philologically correct point of view, the comparative "plus vieux" requires a term of comparison (plus vieux qu'un autre) which does not appear anywhere in the poem.

15. In the myths of the gègeneis or the spartoi, there is a striking image of the warriors growing out of the ground like vegetation, all with a troubling ardor: "who right away begin to fight against each other" (Jean-Pierre Vernant, Mythe et Pensée chez les Grecs: études de psychologie historique [Paris, 1985] I, p. 27). This self-compulsive confrontation seems to be the prototype for Thebes's incestual curse.

16. See Hegel, Phänomenologie des Geistes (Hamburg, 1988), p. 320: "Ohne diese Ehrlichkeit aber gelten die Gesetze nicht als Wesen des Bewusstseins und das Prüfen ebenso nicht als Tun innerhalb desselben." ["Without this honesty of nature, however, laws do not have validity as essential realities of consciousness, and the process of testing likewise does not hold good as an activity inside consciousness"] (Georg Wilhelm Friedrich Hegel, The Phenomenology of the Mind, tr. J. B. Baillie [London, 1977]). 
17. Martha Nussbaum, The Fragility of Goodness (Cambridge, 1986), pp. 64ff, analyzes this "simplification" without any mention of the possible reasons driving Creon's (truly heroic) attempt as a ruler and as Haemon's father to untangle the complex web of contradictory kinship and power relations at Thebes.

18. The pairing of Eteocles and Polyneices thus presents two antagonistic but complementary tendencies--attraction and repulsion--that illustrate, in a narrative way, the principles of unity and differentiation found in Empedocles. See Empedocles' use of philia and neikos in frag. B $17 \mathrm{ff}$. or mixis and diallexis, frag. B 8 (H. Diels and W. Kranz, Die Fragmente der Vorsokratiker, 3 vols. [Zurich, 1964]).

19. This discussion relies to a great extent on Jean-Pierre Darmon's analysis in his "Structures de la parenté," Dictionnaire des Mythologies, 2 vols. (Paris, 1981).

20. The abbreviation H refers to Hölderlin's translation which I prefer here because it goes further in expressing the criminal-like language used by Creon and the Guard.

Kreon: Da schaut ihr dann, woher man den Gewinn hohlt,

Vermacht die Plünderung einander, und erfahrt,

Dass alles nicht gemacht ist zum Erwerbe.

Das weist du gut, durch schlimmen Vortheil sind

Betrogen mehrere, denn wohlbehalten.

Bote: Giebst du, was auszurichten, oder kehr' ich so?

$\mathrm{K}$ : Weisst du, wie eine Quaal jezt ist in deinen Worten?

B: Sticht es im Ohre, stichts im Inneren dir?

$\mathrm{K}$ : Was rechnest du, wo sich mein Kummer finde?

B: Der Täter plagt den Sinn, die Ohren ich.

$\mathrm{K}$ : O mir! Welch furchtbarer Sprechart bist du geboren?

B: So ists, weil ich nicht in der Sache mit bin.

$\mathrm{K}$ : Du bists! Um Geld verratend deine Seele!

21. See Sir James George Frazer, Le Rameau d'Or (Paris, 1923), cap. 14, "La succession au trône dans l'ancien Latium," and p. 147 for specific examples from ancient Greece (that is, Pelops, Jason).

22. Jean-Pierre Vernant, Mythe et Pensée, I, p. 141 s., shows the linguistic and creative linkages between the functions of conqueror and of king. These functions are not only to conquer and rule the land, but also to ensure its prosperity by uniting with it in the manner of man and wife. In addition to certain idiomatic phrases that belie this agrarian, political, and sexual imagery, Vernant mentions the "sacred ploughing" practiced by some priestly family like the Bouzygai who "took over formerly royal rites whose role was not only to initiate and regulate the agrarian calendar, but also to accomplish through this tilling the marriage of a ruler with his land, like that of Jason with Demeter 'in a thrice-plowed field' (Hesiod, Theogony, v. 969ff.)."

23. Orgas here is an adjectival noun (fertile land), with clear sexual overtones.

24. The sexual implications of the adjective orgas / fertile land which Sophocles uses so cleverly are made even clearer in the context of the marriage formula--"I give you this girl for a fruitful harvest of legitimate children" (Menander, Perikeiromene, 435-36, apud Vernant, Mythe et 
Pensée, I, p. 141).

25. The original German reads:

Die zornigste has du angereget

Der lieben Sorgen,

Die vielfache Weheklage des Vaters

Und alles

Unseres Schiksaals,

Uns rühmlichen Labdakiden.

Io! Du mütterlicher Wahn

In den Betten, ihre Umarmungen, selbstgebährend,

Mit meinem Vater, von unglücklicher Mutter,

Von denen eimal ich Trübsinnige kam

(H 886-93, L 856-63)

26. See Martin Heidegger, Einführung in die Metaphysik (Tübingen, 1966), p. 127: "in apprehension the assent as such is disclosed and so comes forth from concealment," tr. R. Manheim, An Introduction to Metaphysics (New Haven, 1959), p. 167--translator's note.

27. See Aristotle, La Poétique (Paris, 1980); Immanuel Kant, Kritik der Urteilskraft (Frankfurt, 1977).

28. "[The poets] do no act in order to portray characters; they include the characters for the sake of the action." The Complete Works of Aristotle, ed. Jonathan Barnes (Princeton, 1995), vol. 2, p. 2320. 